At Turots: Jurnal Pendidikan Islam
Vol. 2, No. 2, Desember 2020, pp. 127-135
Print ISSN : 2656-7555 || Online ISSN : 2747-089X
http://journal.stitmadani.ac.id/index.php/JPI/index

\title{
pengembangan kurikulum bahasa Arab di MAN 4 Bantul
}

\author{
Muhammad Syafii Tampubolon a,1,*, Fathia a,2 \\ a Sekolah Tinggi Ilmu Tarbiyah Madani Yogyakarta, Yokyakarta, Indonesia, 55792 \\ 1 ms2728456@gmail.com; 2 fatiatia61@gmail.com \\ *Correspondent Author
}

KATAKUNCI

Pengembangan Kurikulum Bahasa Arab

Kurikulum 2013

\section{KEYWORDS}

Curriculum Development Arabic

Curriculum 2013
ABSTRAK

Hal mendasar dari kurikulum 2013 adalah masalah pendekatan pembelajarannya. Selama ini, pendekatan yang digunakan adalah materi. Jadi materi di berikan pada anak didik sebanyak-banyaknya sehingga mereka menguasai materi itu secara maksimal. Bahkan demi penguasaan materi itu, drilling sudah diberikan sejak awal, jauh sebelum siswa menghadapi ujian nasional. Dalam pembelajaran seperti ini, tujuan pembelajaran tujuan pembelajaran yang dicapai lebih kepada aspek kgnitif dengan menafikan aspek psikomotrik dan afektif. Ketiga aspek tersebut sebenarnya sudahmendapat penekanan pada kurikulum kita selama ini. Pada saat pemberlakuan Kurikulum Berbasis Kompetensi (KBK) 2003, aspek kognitif, psikomotorik dan afektif (yang dikenal dengan taksonomi Bloom tentang tujuan pendidikan), telah juga menjadi kompetensi integral yang harus dicapai. Lalu pada saat pemberlakuan Kurikulum 2006, melalui pendidikan karakter, aspek afektif yang seolah dilupakan para praktisi pendidikan, digaungkan. Penelitian ini hendak mendeskripsikan bagaimana konsep dan model pengembangan kurikulum 2013 di MAN 4 Bantul.

\section{development of Arabic language curriculum in MAN 4 Bantul}

The fundamental thing from the 2013 curriculum is the problem of the learning approach. So far, the approach used is material. So the material is given to students as much as possible so that they master the material optimally. Even for the sake of mastery of the material, drilling has been given since the beginning, long before students face the national exam. In learning like this, the learning objectives of learning objectives that are achieved are more of the cognitive aspects by negating the psychomotric and affective aspects. These three aspects have actually received emphasis on our curriculum so far. At the time of the implementation of the Competency-Based Curriculum (CBC) 2003, cognitive, psychomotor and affective aspects (known as Bloom's taxonomy of educational goals), have also become integral competencies that must be achieved. Then when the 2006 Curriculum was implemented, through character education, the affective aspects that were seemingly forgotten by education practitioners were echoed. This study intends to describe how the concept and model of curriculum development in 2013 in MAN 4 Bantul Type your abstract here $(10 \mathrm{pt})$. spasi $1 \mathrm{Abstracts}$ are written in two languages, namely Indonesian and English, typed in 1 paragraph 1 space of 150-250 words, containing research points, such as objectives, methods and research results. Keywords are the substance of the research conducted and they are in the title. The format for writing abstracts 
and keywords, as well as the body of the article, must all follow this template.

This is an open-access article under the CC-BY-SA license.

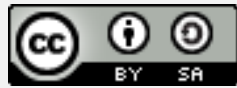

\section{Pendahuluan}

Undang-Undang Nomor 20 Tahun 2003(Irawati \& Susetyo, 2017) tentang Sistem Pendidikan Nasional Pasal 36 ayat (1) menyatakan bahwa "Pengembangan kurikulum dilakukan dengan mengacu pada standar nasional pendidikan untuk mewujudkan tujuan Pendidikan nasional," dan ayat (2) menyebutkan bahwa "Kurikulum pada semua jenjang dan jenis pendidikan dikembangkan dengan prinsip diversifikasi sesuai dengan satuan pendidikan, potensi daerah, dan peserta didik". Pasal 38 ayat (2) menyatakan bahwa "Kurikulum pendidikan dasar dan menengah dikembangkan sesuai dengan relevansinya oleh setiap kelompok atau satuan pendidikan dan komite sekolah atau madrasah di bawah koordinasi dan supervise dinas pendidikan atau kantor Kementerian Agama Kabupaten atau Kota untuk pendidikan dasar dan Provinsi untuk pendidikan menengah.

Dalam rangka melaksanakan perundangan tersebut, telah diterbitkan Peraturan Pemerintah (PP) No.19 Tahun 2005(Alawiyah, 2017) tentang Standar Nasional Pendidikan yang meliputi delapan standar, yaitu standar isi, standar kompetensi lulusan, standar proses, standar penilaian, standar sarana dan prasarana, standar pengelolaan, standar tenaga kependidikan, dan standar pembiayaan. Pasal 17 (ayat 2) PP tersebut menyatakan bahwa "Sekolah dan komite sekolah, atau madrasah dan komite madrasah, mengembangkan kurikulum tingkat satuan pendidikan dan silabusnya berdasarkan kerangka dasar kurikulum dan standar kompetensi lulusan, di bawah supervisi dinas kabupaten atau kota yang bertanggung jawab di bidang pendidikan untuk SD, SMP, SMA, dan MK, dan Kementerian yang menangani urusan pemerintahan di bidang agama untuk MI, MTs, MA, dan MAK.

Sejak keluarnya PP. No. 19 Tahun 2005 secara resmi penyusunan kurikulum menjadi tanggung jawab setiap satuan pendidikan (sekolah dan madrasah), dengan demikian tidak lagi dikenal istilah kurikulum nasional yang dulu menjadi tanggung jawab pemerintah pusat. Hingga saat ini telah terbit tujuh dari delapan Standar Nasional Pendidikan yang seharusnya dijadikan acuan dalam pengembangan dan penyusunan kurikulum sekolah atau madrasah pada jenjang Pendidikan dasar dan menengah.

Modul, Kelas Bahasa Arab, Kelas Bahasa Inggris, kelas MIPA (Matematika dan IPA), kelas Bahasa Indonesia, kelas IPS (Ilmu Pengetahuan Sosial), kelas TIK (Teknologi Informasi dan Komunikasi), kelas POK (Pendidikan Olah Raga dan Kesenian), dan kelas Seni Budaya. Kelas CI+BI merupakan program kelas akselerasi dengan menggunakan kurikulum deferensiasi, kelas Modul menggunakan kurikulum diferensiasi yang menekankan pada aspek pembelajaran dengan menggunakan modul, kelas bahasa Arab menekankan pengembangan kurikulum mata pelajaran PAI dan Bahasa Arab. Kemudian kelas Bahasa Inggris, MIPA, Bahasa Indonesia, IPS, TIK, POK, dan Seni Budaya masing-masing mengorientasikan kurikulum sesuai dengan mata pelajaran yang menjadi fokus utama.

Penelitian ini mengkaji bagaimana konsep dan model pengembangan kurikulum Bahasa Arab di MAN 4 Bantul dan apa saja faktor pendukung dan penghambat pelaksanaan kurikulum tersebut.

\section{Metode}

Penelitian ini termasuk dalam kategori penelitian empiris(Adiyanta, 2019). Metode yang 
digunakan dalam penelitian ini adalah penelitian kualitatif(Prasanti, 2018) karena data yang dikumpulkannya lebih banyak bersifat kualitatif dalam arti data bukan dalam bentuk angka baik interval, ordinal maupun data diskrit sekaligus berusaha menggambarkan realitas sebagaimana adanya (realitas aslinya). Sedangkan jenis penelitian ini adalah eksploratif, yakni studi deskriptif analisis dengan ragam penelitian kasuistis.

Data yang dihimpun adalah data-data yang bersifat kualitatif, yaitu data yang dikategorikan berdasarkan kualitas obyek yang akan diteliti. Di antara data yang dihimpun adalah Konsep kurikulum MAN 4 Bantul, Aplikasi kurikulum MAN 4 Bantul, Implementasi kurikulum MAN 4 Bantul, serta Pendukung dan penghambat realisasi kurikulum di MAN 4 Bantul.

Sumber data dalam penelitian ini, berupa sumber data primer dan data sekunder (penunjang). Data primer diperoleh dari informan atau stakeholder yang terlibat langsung dalam pelaksanaan Pengembangan Kurikulum di MAN 4 Bantul Dalam konteks ini, sumber data primer adalah Wakil Kepala Madrasah bagian kurikulum, staf pengajar bahasa Arab. Sumber data sekunder (penunjang) adalah sumber data yang diambil dari literatur dan dokumen yang terkait dengan penelitian ini, seperti silabus, RPP, struktur kurikulum, peta lokasi, struktur organisasi, jadwal kegiatan dan lain-lain.

Adapun instrumen pengumpul data dalam penelitian ini adalah observasi $(\mathrm{H}$. Hasanah, 2017) non partisipan murni, wawancara mendalam dan dokumentasi. Sedangkan Analisa yang digunakan dalam penelitian ini adalah fungsional and structural prerequisites, yaitu fungsi yang harus sudah ada sebelum unit dibentuk atau didirikan. Demikian pula structural prerequisitis, berarti struktur harus ada sebelum suatu unit dibentuk atau didirikan. Sedangkan untuk menjaga keabsahan temuan, peneliti melakukan pengecekan keabsahan temuannya dengan: (a) perpanjangan, kehadiran, (b) observasi yang diperdalam (observasi lebih lanjut), (c) Triangulasi,(Kasiyan, 2015) (d) audit trail mandiri dan (e) pemeriksaan sejawat melalui diskusi.

\section{Hasil dan Pembahasan}

Madrasah Aliyah Negeri 4 Bantul yang dijadikan sebagai obyek penelitian ini tidak serta merta menjadi sebuah institusi atau lembaga besar yang memiliki kualitas mapan dan meraih prestasi maksimal seperti sekarang ini. Akan tetapi ia adalah sebuah lembaga pendidikan yang memiliki sejarah cukup panjang.

MAN 4 Bantul didirikan tahun 1969 yang merupakan madrasah swasta dengan nama Madrasah Aliyah Laboratorium Fakultas Tarbiyah Sunan Kalijaga Yogyakarta. dan dinegerikan hari Selasa tanggal 23 Juni 2009.

Bermula dari sebuah Madrasah swasta yang dirintis oleh Bapak Drs. Suroyo, M.A. pada 1969 sampai 1979. Lalu pada tahun 1971, kepemimpinan dilanjutkan oleh Ibu Dra. Darojah, S.Pd sampai pada 1973. Kemudian, terus mengalami pergantian sampai saat ini dipimpin oleh Bapak Mohamad Yusuf, S.Ag.

MAN 4 Bantul yang pada awal berdirinya merupakan Madrasah swasta, kemudian dinegerikan pada tahun 2009 memiliki banyak potensi. Di antaranya letak geografisnya sangat strategis sehingga nyaman untuk kegiatan pembelajaran, sarana dan prasarana cukup memadai untuk mendukung kegiatan pembelajaran, anggaran sekolah berasal dari DIPA/BOS serta iuran dari orang/wali siswa, tenaga pendidik

$25 \%$ berpendidikan S-3 dan S-2, selebihnya berpendidikan S-1, prestasi dari siswa MAN Lab UIN juga sangat membanggakan, dan menjalin hubungan kerjasama dengan pihak-pihak terkait seperti UIN Sunan Kalijaga Yogyakarta, UAD, UNY.

Karakteristik MAN 4 Bantul yaitu, siswanya sebagian besar berasal dari luar Daerah Istimewa Yogyakarta yang mempunyai prestasi. Mereka tinggal di Pondok Pesantren atau Panti Asuhan di sekitar MAN 4 Bantul, dan ini memberi dukungan positif. 


\section{Pengembangan Kurikulum Bahasa Arab MAN 4 Bantul}

Prinsip Pengembangan Kurikulum(Prasetyo \& Hamami, 2020) Tingkat Satuan Pendidikan jenjang Pendidikan Dasar dan Menengah dikembangkan oleh Madrasah dan Komite Madrasah berpedoman pada Standar Kompetensi Lulusan dan Standar Isi serta panduan penyusunan kurikulum yang dibuat oleh BSNP. Kurikulum dikembangkan berdasarkan prinsip-prinsip berikut Peningkatan Iman, Takwa, dan Akhlak Mulia, Kebutuhan kompetensi masa depan, Peningkatan potensi, kecerdasan, dan minat sesuai dengan tingkat perkembangan dan kemampuan peserta didik, Keragaman potensi dan karakteristik daerah dan lingkungan, Tuntutan pembangunan daerah dan nasional, Tuntutan dunia kerja, Perkembangan ilmu pengetahuan, teknologi, dan seni, Agama, Dinamika perkembangan global, Persatuan nasional dan nilai-nilai kebangsaan, Kondisi sosial budaya masyarakat setempat, Kesetaraan jender, dan Karakteristik satuan Pendidikan.

Dalam peningkatan iman dan taqwa pihak sekolah mengadakan tahsin $\mathrm{Al}$ Quran bagi siswa yang belum bisa baca Al Quran selama satu bulan awal semester, karena tidak semua siswa di MAN 4 Bantul lulusan dari Madrasah atau pesantren. Kurikulum dikembangkan sesuai dengan kondisi dan ciri khas satuan pendidikan. Kurikulum dikelola berdasarkan prinsip-prinsip sebagai berikut:

a. Berpusat pada potensi, perkembangan, kebutuhan, dan kepentingan peserta didik dan lingkungannya

b. Beragam dan terpadu

c. Tanggap terhadap perkembangan ilmu pengetahuan, teknologi dan seni

d. Relevan dengan kebutuhan kehidupan

e. Menyeluruh dan berkesinambungan

f. Belajar sepanjang hayat

g. Seimbang antara kepentingan nasional dan kepentingan daerah

Prinsip Pelaksanaan Kurikulum di setiap satuan pendidikan menggunakan prinsip-prinsip sebagai berikut;

1) Pelaksanaan kurikulum didasarkan pada potensi, perkembangan dan kondisi peserta didik untuk menguasai kompetensi yang berguna bagi dirinya. Dalam hal ini peserta didik harus mendapatkan pelayanan pendidikan yang bermutu, serta memperoleh kesempatan untuk mengekspresikan dirinya secara bebas, dinamis dan menyenangkan.

2) Kedua, Kurikulum dilaksanakan dengan menegakkan kelima pilar belajar, yaitu; Belajar untuk beriman dan bertakwa kepada Tuhan Yang Maha Esa, Belajar untuk memahami dan menghayati, Belajar untuk mampu melaksanakan dan berbuat secara efektif, Belajar untuk hidup bersama dan berguna bagi orang lain, dan Belajar untuk membangun dan menemukan jati diri, melalui proses pembelajaran yang aktif, kreatif, efektif, dan menyenangkan.

3) Ketiga, Pelaksanaan kurikulum memungkinkan peserta didik mendapat pelayanan yang bersifat perbaikan, pengayaan, dan/atau percepatan sesuai dengan potensi, tahap perkembangan, dan kondisi peserta didik dengan tetap memperhatikan keterpaduan pengembangan pribadi peserta didik yang berdimensi ke-Tuhanan, keindividuan, kesosialan, dan moral.

4) Keempat, Kurikulum dilaksanakan dalam suasana hubungan peserta didik dan pendidik yang saling menerima dan menghargai, akrab, terbuka, dan hangat, dengan prinsip ing ngarsa sung tulada, ing madya mangun karsa, tut wuri handayani, (di depan memberikan contoh dan teladan, di tengah membangun semangat dan prakarsa, di belakang memberikan daya dan kekuatan). 
5) Kelima, Kurikulum dilaksanakan dengan menggunakan pendekatan multistrategi dan multimedia, sumber belajar dan teknologi yang memadai, dan memanfaatkan lingkungan sekitar sebagai sumber belajar, dengan prinsip alam takambang jadi guru (semua yang terjadi, tergelar dan berkembang di masyarakat dan lingkungan sekitar serta lingkungan alam semesta dijadikan sumber belajar, contoh dan teladan).

6) Keenam, Kurikulum dilaksanakan dengan mendayagunakan kondisi alam, sosial dan budaya serta kekayaan daerah untuk keberhasilan pendidikan dengan muatan seluruh bahan kajian secara optimal. Ketujuh, Kurikulum yang mencakup seluruh komponen kompetensi mata pelajaran, muatan lokal dan pengembangan diri diselenggarakan dalam keseimbangan, keterkaitan, dan kesinambungan yang cocok dan memadai antar kelas dan jenis serta jenjang pendidikan.

Struktur kurikulum(Zakaria, 2018) merupakan pola dan susunan mata pelajaran yang harus ditempuh oleh peserta didik dalam kegiatan pembelajaran. Kedalaman muatan kurikulum pada setiap mata pelajaran pada setiap satuan pendidikan dituangkan dalam kompetensi yang harus dikuasai peserta didik sesuai dengan beban belajar yang tercantum dalam struktur kurikulum. Kompetensi yang dimaksud terdiri atas Kompetensi Inti dan kompetensi dasar yang dikembangkan berdasarkan standar kompetensi lulusan. Muatan lokal dan kegiatan pengembangan diri merupakan bagian integral dari struktur kurikulum pada MAN 4 Bantul.

Krukulum nasional(Hidayati \& Prihatin, 2016) mengacu pada standar nasional yang ditetapkan oleh pemerintah dengan model pengembangan dan penyederhanaan beban materi yang ada tanpa menghilangkan esensinya. Untuk mata pelajaran Prakarya dan Kewirausahaan MAN 4 bantul melaksanakan minimal 2 macam. Muatan kurikulum pada tingkat nasional terdiri atas kelompok mata pelajaran A, kelompok mata pelajaran B, dan khusus untuk SMA/MA/SMK/MAK ditambah dengan kelompok mata pelajaran $\mathrm{C}$ (peminatan), termasuk bimbingan konseling dan ekstrakurikuler wajib pendidikan kepramukaan.

Kurikulum Muatan lokal(Amiruddin, 2018) merupakan kegiatan kurikuler untuk melestarikan dan mengembangkan budaya lokal dalam menghadapi tantangan global, yang materinya tidak dapat dikelompokkan ke dalam mata pelajaran yang ada. Substansi muatan lokal ditentukan oleh Madrasah. Kurikulum muatan lokal terdiri atas Bahasa Jawa yang di dalamnya terintegrasi dengan pengajaran Islam dan Piwulang Agung Kraton Ngayogjokarto Hadiningrat. Muatan lokal yang dikembangkan oleh pemerintah daerah provinsi atau kabupaten/kota sesuai dengan kewenangannya dan/atau satuan pendidikan dapat berbentuk sejumlah bahan kajian terhadap keunggulan dan kearifan daerah tempat tinggalnya yang menjadi Bagian mata pelajaran kelompok B; dan/atau Mata pelajaran yang berdiri sendiri pada kelompok B sebagai mata pelajaran muatan lokal dalam hal pengintegrasian tidak dapat dilakukan.

Kurikulum Pengembangan diri(MUNAWAROH, 2015) berbentuk kegiatan pembelajaran bersifat: Mengembangkan pola berfikir, daya kreasi, tanggungjawab melalui pola diskusi dan berorganisasi, Pengenalan dan pembelajaran dengan menggunakan perangkat multimedia, Program Ekstrakurikuler, dan Program sosial kemasyarakatan dengan merealisasikan kepedulian sosial dan kepekaan sosial bernuansa Islami terhadap lingkungan sekitar maupun masyarakat luas.

Struktur Kurikulum MAN 4 Bantul meliputi substansi pembelajaran yang ditempuh dalam satu jenjang pendidikan selama tiga tahun mulai Kelas X sampai dengan Kelas XII. Struktur Kurikulum disusun berdasarkan Standar Kompetensi Lulusan dan Standar Kompetensi mata pelajaran. Pengorganisasian kelas-kelas pada MAN 4 Bantul dibagi ke dalam tiga kelompok, yaitu Kelas X, XI, dan XII merupakan 
program peminatan MIPA dan IPS.

Kurikulum MAN Kelas X terdiri atas 22 mata pelajaran, satu diantaranya sebagai muatan lokal (Bahasa Jawa), 1 mapel sebagai kebijakan Kementerian Agama (Tahfidz), dan 1 mapel sebagai ciri khas madrasah (Karya Ilmiah Remaja). Jam pembelajaran untuk setiap mata pelajaran dialokasikan sebagaimana tertera dalam struktur kurikulum. Satuan pendidikan dimungkinkan menambah atau mengurangi dengan tanpa menghilangkan esensinya. Kelas reguler perhari terdiri dari sembilan (9) jam pelajaran (kecuali hari Jum'at) ditambah enterpreneurship, do'a dzikir dan kegiatan-kegitan lain yang berguna untuk mengasah kecerdasan jasmani dan rohani, meningkatkan rasa cinta tanah air dan nasionalisme. Alokasi waktu satu jam pembelajaran adalah 45 menit. Minggu efektif dalam satu tahun pelajaran (dua semester) adalah 32 minggu.

Kurikulum MAN 4 Bantul Kelas XI terdiri atas 21 mata pelajaran, satu diantaranya sebagai muatan lokal, 1 mapel sebagai kebijakan Kementerian Agama (Tahfidz), dan 1 mapel sebagai ciri khas madrasah (Karya Ilmiah Remaja) yang terintegrasi dengan maple Bahasa Indonesia. Jam pembelajaran untuk setiap mata pelajaran dialokasikan sebagaimana tertera dalam struktur kurikulum. Kelas reguler perhari terdiri dari delapan (9) jam pelajaran (kecuali hari Jum'at) ditambah enterpreneurship, do'a dzikir dan kegiatan-kegitan lain yang berguna untuk mengasah kecerdasan jasmani dan rohani, meningkatkan rasa cinta tanah air dan nasionalisme. Alokasi waktu satu jam pembelajaran adalah 45 menit. Minggu efektif dalam satu tahun pelajaran (dua semester) adalah 32 minggu.

Kurikulum MAN 4 Bantul Kelas XII terdiri atas 21 mata pelajaran, satu diantaranya sebagai muatan lokal, 1 mapel sebagai kebijakan Kementerian Agama. Jam pembelajaran untuk setiap mata pelajaran dialokasikan sebagaimana tertera dalam struktur kurikulum. Kelas reguler perhari terdiri dari sepuluh (9) jam pelajaran untuk kelas XII (kecuali hari Jum'at) ditambah enterpreneurship, do'a dzikir dan kegiatan-kegitan lain yang berguna untuk mengasah kecerdasan jasmani dan rohani, meningkatkan rasa cinta tanah air dan nasionalisme. Alokasi waktu satu jam pembelajaran adalah 45 menit. Minggu efektif dalam satu tahun pelajaran (dua semester) adalah 22 minggu untuk semester pertama dan 16 minggu untuk semester kedua.

Muatan lokal merupakan kegiatan kurikuler untuk mengembangkan kompetensi yang disesuaikan dengan ciri khas dan potensi daerah, termasuk keunggulan daerah, yang materinya tidak sesuai menjadi bagian dari mata pelajaran lain dan atau terlalu banyak sehingga harus menjadi mata pelajaran tersendiri. Substansi muatan lokal(Ma'unah et al., 2020) ditentukan oleh satuan pendidikan, tidak terbatas pada mata pelajaran keterampilan. Muatan lokal merupakan mata pelajaran, sehingga satuan pendidikan harus mengembangkan Standar Kompetensi dan Kompetensi Dasar untuk setiap jenis muatan lokal yang diselenggarakan. Satuan pendidikan dapat menyelenggarakan satu mata pelajaran muatan lokal setiap semester. Ini berarti bahwa dalam satu tahun satuan pendidikan dapat menyelenggarakan dua mata pelajaran muatan lokal

Dengan mengacu pada substansi yang ada MAN 4 Bantul memberikan muatan lokal berdasarkan kebutuhan, lingkungan sosial keagamaan(Sumarto, 2020) dan budaya daerah yaitu pembelajaran Bahasa Jawa X, XI, dan XII, Tahfidz kelas X, XI, dan XII, serta Karya Tulis Ilmiah dimulai dari kelas X.

Pendidikan lingkungan hidup(Asep Turnawan, Indarti Kumala Dewi, 2018) diintegrasikan pada setiap mata pelajaran. Penanaman nilai-nilai kesadaran lingkungan dikembangkan pada setiap mata pelajaran baik secara langsung maupun tidak langsung. Pengembangan diri adalah kegiatan yang bertujuan memberikan 
kesempatan kepada peserta didik untuk mengembangkan dan mengekspresikan diri sesuai dengan kebutuhan, bakat, minat, setiap peserta didik sesuai dengan kondisi MAN 4 Bantul. Pengembangan diri meliputi kegiatan terprogram dan tidak terprogram. Kegiatan terprogram direncanakan secara khusus dan diikuti oleh peserta didik sesuai dengan kebutuhan dan kondisi pribadinya. Kegiatan tidak terprogram dilaksanakan secara langsung oleh pendidik dan tenaga kependidikan di Madrasah yang diikuti oleh semua peserta didik.

Kegiatan terprogram terdiri atas dua komponen; Pelayanan konseling, meliputi pengembangan Kehidupan pribadi, Kemampuan sosial, Kemampuan belajar, dan Wawasan dan perencanaan karier. Ekstrakurikuler meliputi kegiatan Kepramukaan, Latihan kepemimpinan, karya ilmiah remaja, dan PMR, serta Seni, olahraga, jurnalistik, keagamaan.

Kegiatan pengembangan diri tidak terprogram dapat dilaksanakan sebagai berikut: Rutin, yaitu kegiatan yang dilakukan terjadwal seperti Upacara Bendera, senam, ibadah khusus keagamaan, pemeliharaan kebersihan dan kesehatan diri dan kedisiplinan, Spontan, adalah kegiatan tidak terjadwal dalam kejadian khusus seperti pembentukan perilaku memberi salam, membuang sampah pada tempatnya, antri, mengatasi silang pendapat (pertengkaran), dan Keteladanan, adalah kegiatan dalam bentuk perilaku sehari - hari seperti : berpakaian rapi, berbahasa yang baik, rajin membaca, memuji kebaikan, dan atau keberhasilan orang lain dan datang tepat waktu.

Kegiatan pengembangan diri dilakukan melalui berbagai jenis kegiatan di madrasah yaitu Kegiatan layanan konseling(Ramlah, 2018) yang berkenaan dengan masalah diri pribadi dan kehidupan sosial, belajar, dan pembentukan karier peserta didik. Pengembangan diri bagi peserta didik MAN 4 Bantul terutama ditujukan untuk pengembangan kreativitas dan bimbingan karier dan Kegiatan Pengembangan Pribadi dan Kreatifitas siswa bisa dilaksanakan melalui kegiatan Intrakurikuler berupa kegiatan OSIS dan Ekstrakurikuler.

Ekstrakurikuler(Azimah, 2018) dibedakan menjadi dua yaitu Ekstrakurikuler wajib adalah Pramuka diikuti oleh semua siswa kelas X, XI, XII dan BTQ bagi kelas X dan Ekstrakurikuler pilihan yaitu: Musik, Jurnalistik, Hadroh, Kaligrafi, PMR, Olah Raga (tenis meja, voly, basket, badminton), home industry, silat, qiroah, seni gamelan, paskibraka, KIR.

Setiap peserta didik diberikan kesempatan untuk mengikuti kegiatan pengembangan diri baik yang sifatnya wajib maupun yang boleh memilih jenis ekstrakurikuler yang ada di MAN 4 Bantul. Segala aktifitas peserta didik berkenaan dengan kegiatan ekstrakurikuler di bawah pembinaan dan pengawasan guru pembina yang telah ditugasi oleh Kepala Madrasah.

Beban belajar(Huda et al., 2016) yang diatur di MAN 4 Bantul dengan menggunakan Sistem Paket yaitu sistem penyelenggaraan program pendidikan yang peserta didiknya diwajibkan mengikuti seluruh program pembelajaran dan beban belajar yang sudah ditetapkan untuk setiap kelas sesuai dengan struktur kurikulum yang berlaku pada MAN 4 Bantul Beban belajar setiap mata pelajaran pada Sistem Paket dinyatakan dalam satuan jam pembelajaran.

Beban belajar dirumuskan dalam bentuk satuan waktu yang dibutuhkan oleh peserta didik untuk mengikuti program pembelajaran melalui sistem tatap muka, penugasan terstruktur, dan kegiatan mandiri tidak terstruktur. Semua itu dimaksudkan untuk mencapai standar kompetensi lulusan dengan memperhatikan tingkat perkembangan peserta didik.

Kegiatan tatap muka adalah kegiatan pembelajaran yang berupa proses interaksi antara peserta didik dengan pendidik. Beban belajar kegiatan tatap muka per jam pembelajaran di MAN 4 Bantul berlangsung selama 45 menit. Penugasan terstruktur 
adalah kegiatan pembelajaran yang berupa pendalaman materi pembelajaran oleh peserta didik yang dirancang oleh pendidik untuk mencapai standar kompetensi. Waktu penyelesaian penugasan terstruktur ditentukan oleh pendidik. Kegiatan mandiri (tidak terstruktur) adalah kegiatan pembelajaran yang berupa pendalaman materi pembelajaran yang dilakukan oleh peserta didik yang dirancang oleh pendidik untuk mencapai standar kompetensi. Waktu penyelesaiannya diatur sendiri oleh peserta didik. Beban belajar penugasan terstruktur dan kegiatan mandiri (tidak terstruktur) bagi peserta didik pada MAN 4 Bantul maksimum 60\% dari jumlah waktu kegiatan tatap muka mata pelajaran yang bersangkutan. Penyelesaian program pendidikan MAN 4 Bantul dengan menggunakan sistem paket yaitu 3 tahun.

\section{Simpulan}

Pengembangan kurikulum MAN 4 Bantul didasarkan pada prinsip-prinsip berikut:

Pertama, Kurikulum bukan hanya merupakan sekumpulan daftar mata pelajaran karena mata pelajaran hanya merupakan sumber materi pembelajaran untuk mencapai kompetensi. Atas dasar prinsip tersebut maka kurikulum sebagai rencana adalah rancangan untuk konten pendidikan yang harus dimiliki oleh seluruh peserta didik setelah menyelesaikan pendidikannya di satu satuan atau jenjang pendidikan, kurikulum sebagai proses adalah totalitas pengalaman belajar peserta didik di satu satuan atau jenjang pendidikan untuk menguasai konten pendidikan yang dirancang dalam rencana, dan hasil belajar adalah perilaku peserta didik secara keseluruhan dalam menerapkan perolehannya di masyarakat.

Kedua, Kurikulum didasarkan pada standar kompetensi lulusan yang ditetapkan untuk satu satuan pendidikan, jenjang pendidikan, dan program pendidikan. Sesuai dengan kebijakan Pemerintah mengenai Wajib Belajar 12 Tahun(Y. M. Hasanah \& Jabar, 2017) maka Standar Kompetensi Lulusan yang menjadi dasar pengembangan kurikulum adalah kemampuan yang harus dimiliki peserta didik setelah mengikuti proses pendidikan selama 12 tahun. Selain itu sesuai dengan fungsi dan tujuan jenjang pendidikan dasar dan pendidikan menengah serta fungsi dan tujuan dari masingmasing satuan pendidikan pada setiap jenjang pendidikan maka pengembangan kurikulum didasarkan pula atas Standar Kompetensi Lulusan pendidikan dasar dan pendidikan menengah serta Standar Kompetensi satuan pendidikan.

Ketiga, Kurikulum didasarkan pada model kurikulum berbasis kompetensi. Model kurikulum berbasis kompetensi ditandai oleh pengembangan kompetensi berupa sikap, pengetahuan, ketrampilan berpikir, ketrampilan psikomotorik yang dikemas dalam berbagai mata pelajaran. Kompetensi yang termasuk pengetahuan dikemas secara khusus dalam satu mata pelajaran. Kompetensi yang termasuk sikap dan ketrampilan dikemas dalam setiap mata pelajaran dan bersifat lintas mata pelajaran, diorganisasikan dengan memperhatikan prinsip penguatan (organisasi horizontal) dan keberlanjutan (organisasi vertikal) sehingga memenuhi prinsip akumulasi dalam pembelajaran.

\section{Daftar Pustaka}

Adiyanta, F. C. S. (2019). Hukum dan Studi Penelitian Empiris: Penggunaan Metode Survey sebagai Instrumen Penelitian Hukum Empiris. Administrative Law and Governance Journal, 2(4), 697-709. https://doi.org/10.14710/alj.v2i4.697-709

Alawiyah, F. (2017). Standar nasional pendidikan dasar dan menengah. Aspirasi, 8(1), 81-92.

Amiruddin, A. (2018). MUATAN LOKAL DAN TANTANGAN DUNIA KERJA DI MADRASAH ALIYAH PONDOK PESANTREN DDI LIL BANAT KOTA PAREPARE PROVINSI SULAWESI SELATAN. AlQalam, 16(2), 161. https://doi.org/10.31969/alq.v16i2.482

Asep Turnawan, Indarti Kumala Dewi, E. S. (2018). Pengaruh Metode Pembelajaran Inkuiri dan Kreativitas belajar terhadap Pengetahuan tentang lingkungan hidup pada siswa SMA. Jurnal Pendidikan Lingkungan Hidup, 6(2), 1-6. 
Azimah, A. (2018). Optimalisasi Pendidikan Karakter melalui Ekstrakurikuler di SMP Negeri 1 Labuhan Haji Barat Aceh Selatan. DAYAH: Journal of Islamic Education, 1(1), 104. https://doi.org/10.22373/jie.v1i1.2422

Hasanah, H. (2017). TEKNIK-TEKNIK OBSERVASI (Sebuah Alternatif Metode Pengumpulan Data Kualitatif Ilmu-ilmu Sosial). At-Taqaddum, 8(1), 21. https://doi.org/10.21580/at.v8i1.1163

Hasanah, Y. M., \& Jabar, C. S. A. (2017). Evaluasi program wajib belajar 12 tahun pemerintah daerah Kota Yogyakarta. Jurnal Akuntabilitas Manajemen Pendidikan, 5(2), 228. https://doi.org/10.21831/amp.v5i2.8546

Hidayati, I. F., \& Prihatin, T. (2016). Indonesian Journal of Curriculum Pengelolaan Kurikulum Sekolah Alam di TK Alam Al Biruni Cirebon. Indonesian Journal of Curriculum and Educational Technology Studies, 4(299), 32-39.

Huda, K., Kristiyanto, A., \& Doewes, M. (2016). Kerangka Dasar dan Struktur Kurikulum di Sekolah Menengah atas Keberbakatan Olahraga. Kerangka Dasar Dan Struktur Kurikulum Di Sekolah Menengah Atas Keberbakatan Olahraga, 6(1), 28-34. https://doi.org/10.15294/miki.v6i1.9688

Irawati, E., \& Susetyo, W. (2017). IMPLEMENTASI UNDANG-UNDANG NOMOR 20 TAHUN 2003 TENTANG SISTEM PENDIDIKAN NASIONAL DI BLITAR. Jurnal Supremasi, 7(1), 3. https://doi.org/10.35457/supremasi.v7i1.374

Kasiyan, -. (2015). Kesalahan Implementasi Teknik Triangulasi Pada Uji Validitas Data Skripsi Mahasiswa Jurusan Pendidikan Seni Rupa Fbs Uny. Imaji, 13(1), 1-12. https://doi.org/10.21831/imaji.v13i1.4044

Ma'unah, S., Ulfa, S., \& Adi, E. (2020). Pengembangan Kurikulum Muatan Lokal Sebagai Upaya Pelestarian Budaya Seni Musik Hadrah Al-Banjari. JINOTEP (Jurnal Inovasi Dan Teknologi Pembelajaran): Kajian Dan Riset Dalam Teknologi Pembelajaran, 7(1), 42-48. https://doi.org/10.17977/um031v7i12020p042

MUNAWAROH, T. (2015). Peningkatan kemampuan pengembangan diri dalam memakai baju melalui teknik shaping pada siswa tunagrahita ringan kelas iv slb korpri kauman titin munawaroh. Jurnal Pendidikan, 05(3), 53-61.

Prasanti, D. (2018). Model - Model Penelitian Tindakan Kelas. Jurnal Ilmu Komunikasi, 6(1), 13-21.

Prasetyo, A. R., \& Hamami, T. (2020). Prinsip-prinsip dalam Pengembangan Kurikulum. Palapa, 8(1), 42-55. https://doi.org/10.36088/palapa.v8i1.692

Ramlah. (2018). Pentingnya layanan bimbingan konseling bagi peserta didik. Al-Mau'Izhah, 1(September), 70-76.

Sumarto, S. (2020). Pembentukan Perilaku Keagamaan melalui Budaya di Lingkungan Keluarga. Jurnal Hawa : Studi Pengarus Utamaan Gender Dan Anak, 2(1), 92. https://doi.org/10.29300/hawapsga.v2i1.2938

Zakaria, M. (2018). Kerangka Dasar dan Struktur Kurikulum Standar Pendidikan Nasional (Analisis Struktur Fungsi). EL-HIKMAH: Jurnal Kajian Dan Penelitian Pendidikan Islam, 12(1), 22-30. https://doi.org/10.20414/elhikmah.v12i1.233 